\title{
Kollektiv Akademisk Vejledning \\ - et bud på en ændret organisering af vejledningen på universitetet
}

\author{
Rie Thomsen, adjunkt, Forskningsenheden for Vejledning på Institut for \\ Uddannelse og Padagogik, Arts, Aarhus Universitet. \\ Helle Merete Nordentoft, lektor, Forskningsenheden for Vejledning på In- \\ stitut for Uddannelse og Padagogik, Arts, Aarhus Universitet.
}

\begin{abstract}
Artiklen præsenterer et udviklingsarbejde: "Kollektiv Akademisk Vejledning" (KAV) på Master i vejledning på IUP (tidl. DPU), hvor studerende, som skriver individuelle opgaver, vejledes $i$ grupper. For at skabe sammenhæng mellem undervisning og vejledning og dermed kvalificere vejledningen beskriver vi, hvordan vi har integreret tre niveauer $i$ planlægningen af KAV. De tre niveauer er: Vejledningens placering $i$ organisationen, vejledningens forløb på den enkelte uddannelse og struktureringen af selve vejledningsrummet. Det er vores erfaring, at studerende, som deltager $i K A V$, fär en mere sammenhængende, dynamisk og udbytterig skriveproces. Opgaverne er skarpere, mere velskrevne, og de studerende klarer sig bedre til eksamen, fordi deres argumentation er gennemtænkt og afprøvet $i$ vejledningen. Som vejledere har vi farre henvendelser, fordi de studerende $i$ vid udstrækning er velinformerede og bruger hinanden, hvilket giver et bedre samvær mellem de studerende, som ofte bor langt fra hinanden.
\end{abstract}

"It is the tension between diverging voices that creates the potential for new understandings." (Dysthe, Samara, \& Westrheim, 2006).

Intro

Studiemiljøundersøgelsen 2011 på Aarhus Universitet viser, at mange studerende fortsat oplever, at manglende fællesskab og mangelfulde muligheder for faglig sparring er et grundlæggende problem på universitetet, og at nogle studerende fortsat oplever ensomhed på studierne. Undersøgelsen konkluderer, at der er behov for prioritering og nytænkning af vejledningen og dens organisering fx i form af flere forskellige vejledningsaktiviteter og øget brug af peer feedback. I denne artikel præsenterer vi et bud på en samlet og kollektiv vejledningsstrategi, som kan støtte studerende i at skabe større faglig og social sammenhæng i deres studieforløb. Vores argumenter for 
at udvikle en kollektive vejledningsform som pædagogisk praksis på universitetet bygger på følgende antagelser:

1. Kollektive vejledningsformer skaber rammer for videnskabelig argumentation og læring.

2. Studiemiljøet styrkes.

3. STÅ-produktionen øges, fordi kollektive vejledningsformer gør, at flere studerende bliver færdige til tiden.

Vi har valgt betegnelsen Kollektiv Akademisk Vejledning (KAV) for at understrege, at KAV er noget andet end gruppevejledning (se fig. 1). Endvidere har vi ønsket at sende et tydeligt signal om, at netop vejledningen er en central læringsaktivitet i forhold til at udvikle akademiske kompetencer. Formålet med KAV er at stimulere de studerendes studiemotivation og skrivelyst gennem at introducere en kollektiv akademisk arbejdsform via vejledning, hvor de studerende får erfaringer med at præsentere og diskutere faglige spørgsmål i et kollektivt forum. KAV praktiseres derfor i mindre grupper med mulighed for mundtligt med et skriftligt udgangspunkt at øve sig i færdigheder, som knytter sig til videnskabelige kompetencer, der er beskrevet i studieordningen. Ifølge studieordningen for vores uddannelseseksempel - Master i Vejledning 2010 - aflægger de studerende en mundtlig eksamen efter hvert modul, hvor eksaminator og censor vurderer de studerendes kompetencer til at:

- $\quad$ Vurdere centrale teoretiske og praktiske problemstillinger indenfor vejledning.

- $\quad$ Indgå i en teoretisk begrundet diskussion af disse problemstillinger.

- $\quad$ Argumentere for relevante udviklingsmuligheder indenfor undersøgelsesområdet.

Det er vores erfaring, at deltagelse i KAV giver de studerende mulighed for at udvikle og praktisere disse kompetencer.

Vi anvender citatet fra Dysthe til indledningsvist at udtrykke, at KAV bygger på, at en dynamik mellem flere forskellige stemmer skaber mulighed for nye forståelser. I en senere artikel skriver Dysthe og Lillejord desuden, at studerende lærer en central akademisk kompetence: “...by engaging in the most important craft of academic work, the productive process of giving and accepting critique. Not only does this result in better products, they also learn the procedures and standards of the academic community." (Lillejord \& Dysthe, 2008, p. 83). Da KAV bygger på en dynamik mellem forskellige teoretiske perspektiver og projekter kan denne vejledningsform netop danne afsæt for at udvikle de studerendes kompetencer $\mathrm{i}$ at give hinanden kritik og dermed deres videnskabelig argumentation. Deltagelse i KAV forventes 
således at bidrage til, at de studerende socialiseres ind i og lærer de centrale akademiske kompetencer som studieordningen beskriver.

Tidligere forskning i andre kollektive vejledningsformer i masteruddannelser underbygger disse antagelser (Dysthe, et al., 2006). Den tidligere forskning diskuterer dog ikke den faglige vejlednings samspil med undervisningen og med andre vejledningstilbud på en uddannelse. Et af de centrale mål for KAV er at sætte fokus på, hvordan vejledning kan bidrage til at skabe en organisatorisk, strukturel og indholdsmæssig sammenhæng i de studerendes uddannelsesforløb gennem at integrere den faglige vejledning med den vejledning, de studerende har mulighed for at få i skrivecentret og med undervisningen på masteruddannelsen.

Artiklen falder i 3 dele. Først uddyber vi det læringsteoretiske fundament for Kollektiv Akademisk Vejledning. Dernæst uddyber vi, hvordan KAV praktiseres på Master i vejledning på IUP. Vi runder af med at pege på fremtidige forsknings- og udviklingsperspektiver.

Kollektiv Akademisk Vejledning: En gruppe i Kollektiv Akademisk Vejledning består af studerende som arbejder med forskellige projekter men har samme vejleder.

Gruppevejledning: En gruppe i gruppevejledning består af studerende som arbejder med samme projekt og har samme vejleder.

Fig. 1 Definition af Kollektiv Akademisk Vejledning og gruppevejledning.

\section{Læring som deltagelse i KAV}

Det teoretiske grundlag for KAV findes i sociokulturelle læringsteorier, hvor læring knyttes til deltagelse (Lave \& Wenger, 2007). Et sociokulturelt perspektiv indebærer et skift i fokus fra individet som lærende til læring som deltagelse i social praksis. Der lægges vægt på den gensidigt relationelle afhængighed mellem aktør og verden, virksomhed, mening, kognition, læring og indsigt. Denne læringsteoretiske position fremhæver, at "mening forhandles socialt, og at personer i virksomheder (forstået som handlinger) tænker og handler interesseret, engageret." (Lave \& Wenger, 2007 p. 46). Når læring knyttes til deltagelse i social praksis bliver det tydeligt, at den individuelle læring knyttes til mulighederne for at deltage (Dreier, 1999; Højholt, 1996), og dermed skærpes blikket for forskellige deltagelsesmuligheder i de forskellige læringsaktiviteter på universitetet så som forelæsninger, holdundervisning, studiegrupper og vejledning. Læringsaktiviteterne giver de studerende forskellige muligheder for deltagelse og dermed læring. Denne artikel tematiserer integrationen og samspillet mellem KAV og andre læringsaktiviteter. 
Kollektiv Akademisk Vejledning - et udviklingsprojekt på IUP

Udviklingsprojektet startede i 2009 på Masteruddannelsen i Vejledning på IUP (tidl. DPU). Fig. 2 nedenfor viser udviklingen i antallet af kollektive vejledningsgrupper.

\begin{tabular}{|l|l|l|}
\hline Semester & Modul på Master i Vejledning & $\begin{array}{l}\text { Antal vejledningsgrupper } \\
\text { (3-6 studerende og en vejleder) }\end{array}$ \\
\hline E2009 & Modul 1 og 3 & 4 grupper \\
\hline F2010 & Modul 2 og 4 & 9 grupper \\
\hline E2010 & Modul 1 og 3 & 14 grupper \\
\hline F2011 & Modul $2 \operatorname{og} 4$ & 8 grupper \\
\hline E2011 & Modul 1 og 3 & 11 grupper \\
\hline
\end{tabular}

Fig. 2 Antal vejledningsgrupper 2009-2011.

Som figuren viser, har antallet af kollektive vejledningsgrupper været stigende. Udviklingsprojektet har medført, at stort set al vejledning på masteruddannelsen i vejledning er bygget op over denne ramme. Vi er gået fra, at vejlederne hver for sig eksperimenterede med forskellige former for kollektiv tilrettelæggelse til, at vi nu har en fast model for planlægningen af vejledningen, som anvendes på alle moduler.

I vores arbejde med KAV har vi forsøgt at tage højde for de særlige vilkår, studerende på masteruddannelser har til forskel fra fx de fleste studerende på kandidatstudiet. De studerende på Master i vejledning ${ }^{1}$ kommer fra hele landet, og de arbejder sideløbende med, at de studerer, ligesom deres akademiske kvalifikationer er meget vekslende. Nogle har allerede en akademisk uddannelse, mens andre er meget usikre på, hvad der kræves. Vores erfaring er, at mange studerende først tager fat, læser og skriver den sidste måned inden aflevering, hvilket giver et øget pres på vejledningen i den periode. Med udviklingsprojektet KAV ønskede vi at styrke en akademisk kultur, som skaber sammenhæng imellem undervisning og vejledning på trods af, at de studerede ikke har deres daglige gang på universitetet. Ligeledes oplevede vi, at de studerende ikke var gode til at gøre brug af de læringsaktiviteter, som indgik i uddannelsen, eksempelvis benyttede ikke alle sig af skrivecentrets undervisning på modul 4, selvom dette var en del af det 'obligatoriske' undervisningstilbud. Akademisk Skrivecenter blev startet i foråret 2009 for at fremme de studerendes skriveprocesser. Skrivecenteret varetager især de problematiske skriveforløb og arbejder pri-

${ }^{1}$ På Master i vejledning, som vedrører forskellige former for vejledning, men primært uddannelses- og erhvervsvejledning, studievejledning, karrierevejledning og voksenvejledning er der 4 moduler på uddannelsen, 3 grundmoduler og masterprojektmodulet, som er det 4 . modul. 
mært med individuel vejledning og workshops. Samarbejde med skrivecenteret om de studerendes skriveproces kunne derfor styrke og kvalificere forløbet for de studerende på modul 1-3, der har behov for mere vejledning, end rammerne for KAV tillader, samt styrke deltagelsen i den undervisning, som skrivecentret udbyder til studerende på modul 4 på master i vejledning.

\section{Organisering af KAV}

KAV er ikke en metode, som foreskriver, hvad den enkelte vejleder skal foretage sig sammen med sine studerende, når de mødes. KAV kan nærmere betegnes som en ramme, som kan give vejlederen et blik for vejledningens samspil med andre vejlednings- og undervisningstilbud dels i organisationen og dels på den enkelte uddannelse. KAV fordrer dog, at vejlederen tilrettelægger sin vejledning, så de studerende får mulighed for at udveksle forskellige forståelser, tilgange og perspektiver. I udviklingen af KAV har vi været optaget af, at både vejlederne og de studerende får øje for de ressourcer, der er tilgængelige i fællesskabet personligt, professionelt og organisatorisk. Spørgsmålet var - og er - hvordan de studerende kan støttes bedre i forhold til at skabe mening og sammenhæng i deres opgaveskrivningsproces. Ved at tage højde for og integrere nedenstående 3 niveauer for Kollektiv Akademisk Vejledning er det vores erfaring, at vi bedre kan nå dette mål.

1. Vejledningen i organisationen

Samspil mellem KAV og andre læringsaktiviteter og instanser i organisationen $\mathrm{fx}$ akademisk skrivecenter og metodeseminarer (støttecenter/studievejledning mv.).

2. Vejledningen på den enkelte masteruddannelse

Vekselvirkning mellem KAV-møder med de studerende og netværksseminarer for vejledere på grundmoduler (1-3), hvor vejlederne mødes og udveksler spørgsmål og erfaringer som opstart og afslutning på et semester.

Work in progress seminarer på masterprojektmodulet med deltagelse af flere vejledere og studerende (modul 4).

3. Vejledningsrummet

Struktur på vejledningsforløbet i KAV, fokus på fællesskabets ressourcer og didaktiske muligheder. Det kan fx være samarbejds- og feedbackøvelser (Bager, 2008) eller reflekterende teams (Andersen, 2001). 
Kollektiv Akademisk Vejledning - modul 4 masterprojekt

Produktkrav: Skriftlig opgave 50 sider med krav om empiri. Mundtlig eksamination 45 min. Timenorm: 25 timer pr. studerende inklusive eksamination og forberedelse

\section{Opstartsseminar}

Vi udveksler og arbejder med jeres oplæg til masteropgaven. Målet er at gå fra vejledningssessionen med en foreløbig køreplan for det videre arbejde med masterprojektet.

- Valg af emne og motivation

Udkast til problemformulering

Udkast til en disposition for projektet. Hvilke teoretikere og metoder vil I gerne bruge? Hvil-

ken empiri - og hvorfor?

Tidsplan for skriveprocessen

Introduktion til vejledningsprocessen og til sparring med medstuderende?

\section{Workshop i skrivecentret}

\section{Midtvejsrespons}

Vi diskuterer disposition for opgaven og et udvalgt afsnit til respons (teori/analyse). Hvordan analyserer I jeres problemstilling? Ønsker for respons formuleres i spørgsmål der relateres til den vedlagte tekst.

\section{Work-in-Progress seminar}

På et WIP seminar får de studerende lejlighed til at

- $\quad$ Præsentere jeres projekt: Hvad er formålet med projektet, hvorfor og hvordan vil du undersøge det? Teoretisk og empirisk

- Få respons på projektet fra andre vejledere og medstuderende.

Under WIP seminaret

- Hver studerende skal opponere på ét masterprojekt.

- Vejlederne giver respons på et antal projekter, de ikke selv har vejledt.

Denne respons er desuden en fin forberedelse til de spørgsmål og emner, der evt. kan komme til eksamen. Kun de studerende, som sender et skriftligt materiale vil få denne respons under WIP. Studerende, som af forskellige årsager ikke sender materiale til WIP er velkomne til at komme og lytte på.

\section{Strukturen under WIP}

Hvert projekt får ca. 30 min, som er fordelt på følgende måde.

- Den studerende får 5 min. til en kort præsentation af hans/hendes aktuelle spørgsmål/behov. Hvorfor stiller jeg netop disse spørgsmål i det rundsendte materiale? (max 5 minutter).

- Den medstuderende, der opponerer, har nu 7 minutter. Husk den meget simple grundregel for konstruktiv kritik er: Ros-ris-ros. Som opponent må du gerne forholde dig til klarheden i formidlingen. Hvad er det, der undersøges? Hvilke metoder anvendes? Hvilke diskussioner kan rejses på baggrund af projektet? Hvordan ser du sammenhængen mellem disse? Er der passager, hvor du som læser savner viden? Formuler 3 centrale spørgsmål til projektet, som din medstuderende kan forholde sig til.

- Nu er det vejlederens tur til at komme med respons i 7 minutter.

- Til slut er der små 10 minutter til en afsluttende diskussion af de perspektiver, der er rejst indtil nu. Her kan andre medstuderende og vejledere få lejlighed til at komme med kommentarer/spørgsmål.

- Afslutningsvis spørger vi den studerende, hvad hans/hendes næste skridt i skriveprocessen er. Hvor har WIP seminaret bragt dig hen i din skriveproces?

Under opponeringen må opponenterne ikke afbrydes. Den studerende, som modtager respons kan sidde og lytte, skrive ned - og efter responsen får han/hun lejlighed til at stille uddybende spørgsmål/kommentere på det, som er blevet sagt. Det er en god idé at undgå lange forklaringer og i stedet spørge ind til, hvordan det er muligt at arbejde videre med de uklarheder, som opponeringen har rejst.

\section{Vejledningsgang:}

Vejlederne har afsat denne dag til vejledning af de studerende, som har brug for det. Via mail, telefon eller face2face.

Fig. 3 Plan over Kollektiv Akademisk Vejledning. 


\section{Vejledningen i organisationen}

I beskrivelsen af "vejledningen i organisationen" har vi har valgt at fokusere denne artikel på modul 4, som er det afsluttende modul på Master i vejledning, hvor ressourcerne til undervisning og vejledning er fordelt på flest forskellige personer. Ressourcerne til undervisning på dette modul tilfalder modul 4-koordinatoren, som udbyder to workshops om metode, og de tilfalder skrivecentret, som ligeledes udbyder to workshops.

En central udfordring på modul 4 har været, at de studerende (og vejlederne) så skrivecentrets workshops som et tilbud, de studerende kunne tage i mod eller lade være. Denne opfattelse har fx betydet, at mange studerende ikke har prioriteret deltagelse i disse workshops og ofte (for) sent i deres skriveforløb har taget kontakt med skrivecentret på vejlederens anbefaling. Integrationen af skrivecentrets workshops og metodekurset på modul $4 \mathrm{i}$ en samlet oversigt til de studerende sammen med KAV har bevirket, at de studerendes (og vejledernes) blik for samspillet mellem vejledning og de andre aktiviteter på modul 4 er blevet skærpet. Konkret har det betydet, at flere studerende på master i vejledning deltager i de forskellige læringsaktiviteter på modul 4.

Vores udviklingsarbejde peger således på, at der har manglet koordination mellem udbyderne af de forskellige læringsaktiviteter. Der kan nemt opstå problemer med sammenfald i datoer, sammenfald i indhold eller ved, at studerende fravælger aktiviteter, fordi de tror, at indholdet i nogle læringsaktiviteter er det samme, eller at de studerende tror, at aktiviteten ikke er en del af læringsaktiviteterne på deres uddannelse men derimod et generelt tilbud. Hvis KAV skal lykkes, er planlægning og koordination mellem de forskellige læringsaktiviteter nødvendig.

På modul 1-3, hvor vi også har tilrettelagt vejledningen som KAV, men selv planlægger undervisningen, har vi valgt at indarbejde KAV i de seminarer, vi udbyder. Typisk fordeler undervisningen på modul 1-3 sig over 10 dage fordelt på 4 seminarer. Vi har bemærket, at flere og flere studerende efterspørger datoer for kommende semestres undervisning (og vejledning og eksamen) sådan, at de kan få lagt dem ind i deres arbejdskalender. At vejledningen er en del undervisningsplanen sender et tydeligt signal om, at vejledning er lige så vigtig som forelæsninger. Denne prioritering understøtter de studerendes muligheder for at møde op til vejledningen, fordi datoerne er kendt på forhånd og derfor kan forhandles på plads med arbejdsgiver $\mathrm{i}$ god tid. Indlejringen af KAV i undervisningsplanen betyder, at flere møder op til vejledningen. 


\section{Vejledningen på den enkelte masteruddannelse}

I begyndelsen medførte ændringerne spørgsmål fra de studerende vedrørende rimeligheden af, at deres timer til vejledning blev samlet i en pulje og anvendt til en anden form for vejledning end den, de tidligere havde kendt eller forventede. Efterhånden som flere vejledere begyndte at anvende KAV som ramme for deres vejledning, fulgte en periode, hvor vi lod det være op til de studerende selv at vælge hvilken form for vejledning, de ønskede at deltage i. Denne form har vi forladt. I modsætning til Lillejord \& Dysthe (2008) tilbyder vi ikke eksplicit individuel vejledning på Master i vejledning. Dette har to begrundelser: For det første mener vi, at KAV giver de studerende mulighed for at deltage i aktiviteter, som gør det muligt at lære de kompetencer, som beskrives i studieordningen for master i vejledning. For det andet er timerne til vejledning begrænsede, og KAV er bygget op omkring, at timerne til vejledning anvendes $\mathrm{i}$ et fælles forløb og dermed ikke er til den enkelte studerendes rådighed og prioritering. Vi har en forventning om, at hvis vi lod det være op til de studerende at vælge mellem kollektiv og individuel vejledning, så ville mange vælge individuel vejledning af den simple grund, at det er det, de kender til. Vi har ønsket at gøre KAV til normen og den individuelle vejledning til undtagelsen. I praksis har det været sådan, at de studerende, som af forskellige årsager har efterspurgt et individuelt forløb fx pga. af afstand til DPU, arbejdsforhold eller andre begrundelser har fået individuel vejledning. Vi har dog opfordret dem til at følge de samme datoer som deres medstuderende, da vi oplever, at KAV samler vejledningen, sådan at vejledning af de studerende ikke kommer drypvis og spredes over mange dage. På den måde kan Kollektiv Akademisk Vejledning fungere som en ramme for vejledningen, der kan skabe mere sammenhængende og koncentreret vejledningstid for vejlederen og for de studerende. Samtidigt viser vores erfaringer, at studerende, som vejledes individuelt, også kommer tidligere i gang med deres opgaver, hvis de fleste studerende følger et KAV forløb.

\section{Vejledningsrummet}

I forhold til vejledningsrummet har vi formuleret nogle få centrale anvisninger for KAV. For det første bygger KAV på, at der udveksles perspektiver og forståelser i vejledningsrummet. Dysthe m.fl. betegner spænding mellem divergerende stemmer som fundamentet for nye forståelser (Dysthe, Samara \& Westrheim, 2006). Denne spænding har gode vilkår i KAV, da en gruppe udgøres af studerende som arbejder med at undersøge forskellige problemstillinger og ofte anvender forskellige teoretiske og metodiske tilgange i deres projekter. For at de studerende og vejlederen kan forberede sig til KAV, er det vigtigt, at de studerende forud for vejledningen udveksler skriftligt materiale. Materialet kan være mere eller mindre omfattende. Kravene til materialet er specificeret af vejleder mht. indhold og omfang. I det skriftlige materiale skal de studerende også formulere deres spørgsmål/vejledningsbehov for at 
skærpe de studerendes opmærksomhed på, hvad de gerne vil have ud af at deltage i vejledningen. For at vejledningen kan stimulere akademiske dialoger, er det vigtigt, at vejledningen bliver mere end en tilbagemelding på de studerendes materiale. Tid til fælles diskussion skal derfor indgå i vejlederens planlægning og styring af vejledningen. Vejledningen bliver mere varieret, end der har været tradition for, da der er en vekselvirkning mellem kollektive og individuelle input og øvelser. Netværksseminarerne viser, at KAV giver anledning til større variation i vejledningen. Denne variation kan betyde, at vejledningen når og tilgodeser flere forskellige læringsbehov hos de studerende. Samtidig siger vejlederne, at det kan være en udfordring ikke at falde tilbage til en asymmetrisk kommunikation i vejledningen, hvor vejlederen er eksperten, som giver feedback til hver enkelt studerende på skift, uden at inddrage de andre studerende i gruppen. Denne problematik har fået nogle vejledere til at efterspørge konkrete aktiviteter som fx struktureret feedback, feedback-spil, reflekterende teams mv. Flere vejledere har ganske enkelt sagt, at de oplever at mangle kompetencer til at inkludere forskellige aktiviteter i vejledningen og facilitere gruppeprocesser. KAV byder således på en række muligheder men er også forbundet med en række udfordringer. I punkterne nedenfor kommer vi derfor med anbefalinger til en vejleder, som ønsker at praktisere KAV.

- Vær tydelig om struktur, indhold og forventninger - også gerne indledningsvis og som afslutning på hver vejledningsgang.

- Vær opmærksom på, at alle får plads og respons til vejledningen.

- Sæt tid af til fælles faglige diskussioner, som udspringer af de konkrete projekter. Her træner de studerende argumentation med dig og med hinanden og udvikler akademiske kompetencer. (jf. målene i studieordningen).

- Vær opmærksom på at tilbyde deltagelsesmuligheder i den kollektive vejledning til usikre studerende (lav fx parøvelser).

\section{Fremtidige perspektiver}

Udviklingsprojektet Kollektiv Akademisk Vejledning har styrket vejledningens samspil med og placering i forhold til andre læringsaktiviteter på IUP. Ligeledes har KAV givet de studerende mulighed for at udvikle og praktisere kompetencer, som er nævnt i studieordningen for masteruddannelsen. KAV byder dog også på en lang række udfordringer for ønsket om at differentiere vejledning i et kollektivt forum, som vi dags dato stadigt arbejder med at håndtere og kvalificere i udviklingen af KAV. De vejledere, som har deltaget i udviklingsprojektet, har værdsat at mødes og udveksle erfaringer om vejledning på de to vejledermøder, vi har i forbindelse med 
KAV på de enkelte moduler. Disse møder og vejledernes ønske om at blive bedre til at vejlede kollektivt har resulteret $i$ et kompetenceudviklingsprojekt ${ }^{2}$, som har fået midler fra studiemiljøpuljen på IUP, Arts, i efteråret 2011. Senere er det vores håb, at der er interesse for at gentage kompetenceudviklingsprojektet på andre institutter på Arts.

Rie Thomsen er adjunkt ved Forskningsenheden for Vejledning på Institut for Uddannelse og Pædagogik, Arts, Aarhus Universitet. Centrale områder i Ries forskningsarbejde er karrierevejledning. Hendes afhandling Vejledning i fællesskaber har bragt inspiration til det danske vejledningsfelt ved at sætte fokus på: Hvordan vejledning far betydning $i$ de vejledtes liv, at en vejledning som foregår i fxllesskaber byder på andre deltagelsesmuligheder end en vejledning, som foregår individuelt og, at deltagerne $i$ vejledningen også påvirker og forandrer vejledningspraksis og derigennem skaber nye muligheder for den enkelte og for fxllesskabet. Hun har netop afsluttet en undersøgelse af efterskolernes vejledning, samt en artikel om dialektikbegrebet $i$ dansk, kritisk psykologi.

Helle Merete Nordentoft, er lektor ved Forskningsenheden for Vejledning på Institut for Uddannelse og Pædagogik, Arts, Aarhus Universitet. Helle er tidligere sygeplejerske, sundhedsfaglig supervisor og cand. comm. Kommunikation og kollektive vejledningsformer $i$ det sundhedsfaglige felt står derfor centralt $i$ hendes forskning. Omdrejningspunktet i forskningen er, hvordan vejledning - også i en universitetspædagogisk sammenhæng - gennem at bringe forskellige faglige/personlige perspektiver sammen kan skabe rammer for udvikling og læring.

Rie Thomsen og Helle Merete Nordentoft har sammen initieret et universitetspæedagogisk udviklingsprojekt om kollektive vejledningsformer, som har resulteret i udviklingen af Kollektiv Akademisk Vejledning som model for vejledning ved universitetet. Dette projekt videreføres $i$ en forbindelse med et projekt som dels søger at udvikle vejlederkompetencer i forbindelse med l kollektiv vejledning og dels undersøger kollegial vejledning som modus for udvikling og implementering af Kollektiv Akademisk Vejledning på universitetet.

\section{Litteratur}

Andersen, T. (2001). Reflekterende Processer. Samtaler og samtaler om samtalerne. København: Dansk Psykologisk Forlag.

Bager, L. T. (2008). "Cafemodellen: Anerkendende feedback i projektgrupper", in Dansk Universitetspædagogisk Tidsskrift, 3(6).

Dreier, O. (1999). "Læring som ændring af personlig deltagelse i sociale kontekster", in Nielsen K. \& Kvale S. (Eds.): Mesterlære. Kbh: Hans Reitzels Forlag.

${ }^{2}$ Projektet ledes af artiklens forfattere sammen med lektor Gitte Wichman-Hansen, AAU. I projektet optager vejlederne deres vejledning på video, vælger et klip og viser dette klip for de andre vejledere i projektet på netværksmøder. 
Dysthe, O., Samara, A., \& Westrheim, K. (2006). "Multivoiced supervision of master's students: a case study of alternative supervision practices in higher education", in Studies in Higher Education, 31 (3), 299-318.

Højholt, C. (1996). Udvikling gennem deltagelse Skolelivets socialpsykologi. København: Unge pædagoger.

Lave, J., \& Wenger, E. (2007). Situeret læring - og andre tekster. Kbh.: Hans Reitzels Forlag.

Lillejord, S., \& Dysthe, O. (2008). "Productive learning practice - a theoretical discussion based on two cases", in Journal of Education and Work, 21 (1), 75-89. 